\title{
KAJIAN TERHADAP NILAI-NILAI SOSIAL DALAM KUMPULAN CERPEN "RUMAH MALAM DI MATA IBU" KARYA ALEX R. NAINGGOLAN SEBAGAI ALTERNATIF BAHAN AJAR
}

\author{
Eny Tarsinih \\ Prodi Pendidikan Bahasa dan Sastra Indonesia \\ Universitas Wiralodra \\ e-mail: enytarsinih18@gmail.com
}

\begin{abstract}
ABSTRAK
Banyak remaja yang berperilaku tidak sesuai dengan nilai sosial yang ada di masyarakat, guru dan siswa belum secara optimal mengambil pelajaran dari nilai sosial yang terkandung dalam karya sastra, bahan ajar sastra di SMA sangat kurang, karena guru biasanya hanya mengajarkan apa yang disajikan dalam buku paket siswa saja, dan media yang digunakan masih monoton.

Berdasarkan latar belakang masalah di atas, rumusan masalah dalam penelitian ini sebagai berikut. (1) Bagaimana struktur cerpen yang terdapat dalam kumpulan cerpen "Rumah Malam di Mata Ibu" Karya Alex R. Nainggolan? (2) Bagaimana nilai-nilai sosial yang terdapat dalam kumpulan cerpen "Rumah Malam di Mata Ibu" Karya Alex R. Nainggolan (3) Apakah semua cerpen dalam kumpulan cerpen "Rumah Malam di Mata Ibu" Karya Alex R. Nainggolan dapat dijadikan sebagai bahan ajar? Penelitian ini merupakan penelitian kualitatif. Metode penelitian yang peneliti gunakan adalah metode deskriptif kualitatif. Metode tersebut digunakan untuk mendeskripsikan sosiologi sastra, struktur cerpen, nilai sosial, dan bahan ajar.

Berdasarkan hasil penelitian, dapat disimpulkan bahwa: (1) Cerpen-cerpen yang terdapat pada kumpulan cerpen "Rumah Malam di Mata Ibu" Karya Alex R. Nainggolan memuat tema antara lain Asmara, kurangnya kasih sayang dalam keluarga, dan sulitnya perekonomian keluarga; menggunakan alur maju menggunakan sudut pandang pesona pertama dan ketiga, mengandung amanat antara lain kesabaran dan keikhlasan menjalani hidup, dan menghargai orang lain, (2) nilai sosial yang terdapat dalam cerpen Rumah Malam di Mata Ibu Karya Alex R. Nainggolan, antara lain persahabatan, hormat pada orang tua, dan rela berkorban; (3) cerpen tersebut menggunakan bahasa sehari-hari, terdapat pembelajaran yang dapat mereka pelajari di usia remaja seperti hormat kepada orang tua dan rela berkorban demi orang lain; (4) model pembelajaran yang digunakan adalah pembelajaran kooperatif karena karya sastra khususnya cerpen terdapat persoalan yang harus dipecahkan dan dikaitkan dengan kehidupan nyata siswa, sehingga dengan model tersebut siswa menganalisis dan mempelajari bagaimana hubungan karya sastra dengan kehidupan.
\end{abstract}

Kata kunci: kumpulan cerpen, perilaku di lingkungan sosial, nilai sosial, dan bahan ajar.

\section{PENDAHULUAN}

Karya sastra merupakan hasil kreasi sastrawan melalui kotemplasi dan refleksi setelah menyaksikan berbagai fenomena kehidupan dalam lingkungan sosialnya (Al-
Ma'ruf, 2009: 1). Karya sastra merupakan hasil kreatif pengarang yang menuangkan tulisannya dalam cerita. Karya sastra merupakan hasil karya manusia. Keberadaan karya sastra menjadi penggambaran 
fenomena kehidupan masyarakat. Suatu karya cenderung menampilkan cerita seputar kehidupan sehari-hari. Menurut Al-Ma'ruf (2010: 15) cerpen merupakan salah satu genre sastra di samping novel, puisi, dan drama. Cerpen adalah cerita atau rekaan (fiction), disebut juga teks naratif (narrative text) atau wacana naratif (narrative discourse). Penelitian ini membahas struktur yang membangun, nilai sosial dan implementasi Cerpen "Rumah Malam di Mata Ibu" karya Alex R. Nainggolan.

Tujuan dari penelitian ini untuk mendeskripsikan struktur, nilai sosial dan implementasi kumpulan cerpen "Rumah Malam di Mata Ibu" karya Alex R. Nainggolan. Menurut Stanton (2007: 20-22) menyatakan bahwa karya sastra terdiri atas unsur fakta cerita, tema, dan sarana sastra. Fakta cerita terdiri dari tiga unsur yaitu: alur (plot), tokoh, dan latar, sedangkan sarana sastra biasanya terdiri atas sudut pandang, gaya bahasa dan suasana, simbol-simbol, imajinasi, dan juga cara-cara pemilihan judul dalam karya sastra.

Sosiologi sastra merupakan penelitian yang berawal dari penafsiran dan analisis karya sastra itu sendiri. Menurut Endraswara (2013: 77) sosiologi sastra adalah cabang penelitian sastra yang bersifat reflektif. Horton dan Hunt (1987: 71) menyatakan bahwa nilai adalah gagasan mengenai apakah pengalaman berarti atau tidak berarti. Nilai adalah sesuatu yang berharga dan berguna bagi masyarakat. Arzia (2011: 62) menyatakan bahwa nilai sosial adalah sebuah konsep abstrak dalam diri manusia pada sebuah masyarakat mengenai apa yang dianggap baik dan apa yang dianggap buruk, indah atau tidak indah, dan benar atau salah.

Bahan ajar adalah segala bentuk yang digunakan untuk membantu guru atau instruktur dalam melaksanakan proses pembelajaran di kelas. Waluyo (2002: 68) berpendapat bahwa karya sastra hadir sebagai wujud nyata imajinatif kreatif seorang sastrawan dengan proses yang berbeda antara pengarang yang satu dengan pengarang yang lain, terutama dalam penciptaan cerita fiksi. Proses tersebut bersifat individualis artinya cara yang digunakan oleh tiap-tiap pengarang dapat berbeda. Perbedaan itu meliputi beberapa hal di antaranya metode, munculnya proses kreatif, dan cara mengekspresikan apa yang ada dalam diri pengarang hingga bahasa penyampaian yang digunakan.

Sastra sebagai hasil pekerjaan seni kreasi manusia tidak akan pernah lepas dari bahasa yang merupakan media utama dalam karya sastra. Sastra dan manusia erat kaitannya karena pada dasarnya keberadaan sastra sering bermula dari persoalan dan permasalahan yang ada pada manusia dan lingkungannya, kemudian dengan adanya imajinasi yang tinggi seorang pengarang tinggal menuangkan masalah-masalah yang ada di sekitarnya menjadi sebuah karya sastra.

Cerpen ini menarik untuk dianalisis karena dalam cerpen ini menceritakan realita kehidupan dunia malam seorang wanita demi bertahan hidup sampai menemukan sosok yang ia cari selama ini. Karena itu, peneliti mendeskripsikan nilai sosial dengan kajian sosiologi sastra dalam kumpulan cerpen "Rumah Malam di Mata Ibu" karya Alex R. Nainggolan. Berdasarkan latar belakang di atas, penulis memandang perlu untuk mengangkat masalah tersebut dengan judul "Nilai-Nilai Sosial dalam Kumpulan Cerpen Rumah Malam di Mata Ibu Karya Alex R. Nainggolan dengan Kajian Sosiologi Sastra sebagai Alternatif Bahan Ajar."

\section{KERANGKA TEORI}

\section{Cerpen}

\section{a) Pengertian Cerpen}

Cerpen adalah karangan pendek yang berbentuk prosa. Dalam cerpen dipisahkan sepenggal kehidupan tokoh, yang penuh pertikaian, peristiwa yang mengharukan atau menyenangkan, dan mengandung kesan yang tidak mudah dilupakan (Kosasih dkk, 2004: 431). Cerpen atau dapat disebut juga dengan cerita pendek merupakan suatu bentuk prosa naratif fiktif. Cerpen cenderung singkat, padat, dan langsung pada tujuannya 
dibandingkan karya-karya fiksi lain yang lebih panjang, seperti novelet dan novel.

Cerpen merupakan salah satu jenis karya sastra yang memaparkan kisah atau cerita mengenai manusia beserta seluk beluknya lewat tulisan pendek dan singkat. Atau pengertian cerpen yang lainnya yaitu sebuah karangan fiktif yang berisi mengenai kehidupan seseorang ataupun kehidupan yang diceritakan secara ringkas dan singkat yang berfokus pada suatu tokoh saja. Menurut KBBI, cerpen berasal dari dua kata yaitu cerita yang mengandung arti tuturan mengenai bagaimana sesuatu hal terjadi dan relatif pendek berarti kisah yang diceritakan pendek atau tidak lebih dari 10.000 kata yang memberikan sebuah kesan dominan serta memusatkan hanya pada satu tokoh saja dalam cerita pendek tersebut. Sedangkan menurut Nugroho Notosusanto dalam Tarigan. Cerpen atau cerita pendek yaitu sebuah cerita yang panjang ceritanya berkisar 5000 kata atau perkiraan hanya 17 hlm kuarto spasi rangkap serta terpusat pada dirinya sendiri.

Cerpen ialah sebuah cerita yang singkat yang harus memiliki bagian terpenting yakni perkenalan, pertikaian, serta penyelesaian. Pendapat orang tentang cerpen sangat berbeda, masing-masing pendapatnya sangat baik dan memiliki perbedaanuntuk itu saya berpendapat cerpen ialah suatu karangan yang berkisah pendek yang mengandung kisahan tungal, menurut pendapat H. B. Jassin (2003: 89).

\section{b) Jenis-Jenis Cerpen}

Berdasarkan jumlah kata cerpen dibagi menjadi 3 yaitu:

1. Cerpen mini (flash) adalah cerpen dengan jumlah kata antara 750-1000 kata.

2. Cerpen yang ideal adalah cerpen dengan jumlah kata antara 3000-4000 kata.

3. Cerpen panjang, adalah cerpen yang jumlah kata 4000-10.000 kata.

Berdasarkan teknik pengarangnya cerpen dibagi menjadi dua sebagai berikut.
1. Cerpen sempurna adalah teknik penulisan cerpen oleh pengarang dimana cerpen yang ditulis hanya terfokus pada satu tema dan memiliki plot yang sangat jelas, serta ending atau penyelesaiannya mudah dipahami. Cerpen jenis ini pada umumnya bersifat konfensional dan berdasar pada realitas (fakta).

2. Cerpen tak utuh adalah teknik penulisan cerpen dimana pengarang menulis cerpen dengan tidak terfokus pada suatu tema atau berpencar, susunan plot atau alurnya tidak tertata, serta endingnya mengambang. Cerpen jenis ini umumnya bersifat kontemporer dan ceritanya ditulis berdasarkan gagasan atau ide yang orisinil.

\section{c) Ciri-ciri Cerpen}

Berdasarkan beberapa pengertian cerpen di atas menurut Wicaksono (2005: 55) dapat mencirikan cerpen adalah sebagai berikut.

1. Jalan ceritanya lebih pendek dari novel

2. Sebuah cerpen memiliki umlah kata yang tidak lebih dari 10.000 (10 ribu) kata

3. Biasanya isi cerita cerpen berasal dari kehidupan sehari-hari

4. Tidak menggambarkan semua kisah para tokohnya, hal ini karena dalam cerpen yang digambarkan hanyalah inti sarinya saja.

5. Tokoh dalam cerpen digambarkan mengalami masalah atau suatu konflik hingga pada tahap penyelesaiannya.

6. Pemakaian kata yang sederhana serta ekonomis dan mudah dikenal pembaca.

7. Kesan yang ditinggalkan dari cerpen tersebut sangat mendalam sehingga pembaca dapat ikut merasakan kisah dari cerita tersebut.

8. Biasanya hanya 1 kejadian saja yang diceritakan. 
9. Memiliki alur cerita tunggal dan lurus.

10. Penokohan pada cerpen sangatlah sederhana, tidak mendalam serta singkat.

\section{d) Unsur Intrinsik Cerpen}

Unsur intrinsik merupakan unsur pembangunan karya sastra yang berasal dari dalam karya itu sendiri, menurut Nurgiantoro (2009: 23). Pada cerpen unsur instrinsik itu berupa: tema, alur/Plot, setting, tokoh, penokohan, sudut pandang, gaya bahasa, dan amanat.

\section{e) Unsur Ekstrinsik Cerpen}

Unsur ekstrinsik cerpen merupakan sebuah unsur yang membentuk cerpen dari luar, berbeda dengan unsur intrinsik cerpen yang membentuk cerpen dari dalam. Unsur ekstrinsik cerpen tidak terlepas dari keadaan masyarakat saat dimana cerpen tersebut dibuat oleh pengarang. Unsur ini sangat memiliki banyak sekali pengaruh terhadap penyajian amanat ataupun latar belakang dari cerpen tersebut. Nurgiantoro (2009: 23). Sedangkan menurut Wellek \& Werren (1956), unsur ekstrinsik adalah unsur-unsur yang berada di luar karya sastra, tetapi secara tidak langsung memengaruhi bangunan atau sistem organisme karya sastra. Unsur ekstrinsik berperan sebagai unsur yang memengaruhi bangunan cerita. Sebagimana halnya unsur instrinsik, unsur ekstrinsik terdiri atas beberapa unsur sebagai berikut. (1) Keadaan subjektivitas individu pengarang misalnya: keyakinan, dan pandangan hidup. (2) Keadaan psikologis, pengarang, pembaca, atau penerapan prinsip psikologis dalam karya. (3) Keadaan lingkungan pengarang, seperti ekonomi, sosial, dan politik. (4) Pandangan hidup suatu bangsa, berbagai karya seni, agama, dan sebagainya.

\section{f) Kriteria Bahan Ajar}

Pelaksanaan pembelajaran apresiasi sastra anak di sekolah dasar dapat dimulai dari kegiatan pra-KBM (Kegiatan Belajar Mengajar) hingga KBM di kelas. Kegiatan
pra-KBM dapat dilakukan dengan memberi salinan atau kopi teks sastra, diberi tugas membaca, menghafalkan, meringkas atau mencatat dan menemukan arti kata-kata sukar yang terdapat dalam teks sastra. KBM di kelas dapat dilakukan dengan memberi tugas membaca sajak, membaca cerita, berdeklamasi atau mendongeng di depan kelas, Setelah itu baru diadakan tanya jawab, menuliskan pendapat, dan berdiskusi bersama merumuskan isi, tema, dan amanat. Sebelum melaksanakan pemilihan bahan ajar, terlebih dahulu perlu diketahui kriteria pemilihan bahan ajar. Kriteria pokok pemilihan bahan ajar atau materi pembelajaran adalah standar kompetensi dan kompetensi dasar. Hal ini berarti bahwa materi pembelajaran yang dipilih untuk diajarkan pada siswa hendaknya berisi materi atau bahan ajar yang benar-benar menunjang tercapainya standar kompetensi dan kompetensi dasar. Dengan kata lain, pemilihan bahan ajar haruslah mengacu atau merujuk pada standar kompetensi.

\section{g) Teori Sosiologi Sastra}

Sosiologi berasal dari akar kata Yunani sosio (socius berarti bersama sama, bersatu, kawan, teman) dan logi (logos berarti sabda, perkataan, perumpamaan). Sosiologi berarti ilmu mengenai asal usul dan pertumbuhan (evolusi) masyarakat, ilmu pengetahuan yang mempelajari keseluruhan jaringan hubungan antarmanusia dalam masyarakat, sifatnya umum, rasional, dan empiris. Sastra bersifat lebih spesifik sesudah terbentuk menjadi kata jadian, yaitu kesusastraan, artinya kumpulan hasil yang baik. karya sastra yang jelas bersifat evaluatif, subjektif, dan imajinatif. Perbedaaan antara sastra dan sosiologi merupakan perbedaan hakikat, sebagai perbedaan ciri-ciri, sebagaimana ditujukan melalui perbedaan antara rekaan dan kenyataan, fiksi dan fakta Ratna (2013: 1).

\section{METODE PENELITIAN}

Metode yang digunakan dalam penelitian ini adalah metode kualitatif. 
Penulis memilih metode tersebut karena analisis data dilakukan pada kondisi objek yang alamiah. Menurut Sugiyono (2014: 1), metode penelitian kualitatif/naturalistik adalah metode penelitian yang digunakan untuk meneliti pada kondisi objek yang alamiah, peneliti adalah sebagai instrumen kunci, teknik pengumpulan data dilakukan secara triangulasi (gabungan) yakni pengumpulan data dengan menggunakan berbagai sumber dan berbagai teknik pengumpulan data secara simultan untuk mendapatkan data yang pasti, analisis data bersifat induktif berdasarkan fakta-fakta yang ditemukan yang kemudian dapat dikonstruksikan menjadi hipotesis atau teori, dan hasil penelitiannya lebih menekankan makna yaitu data yang sebenarnya atau data yang pasti yang merupakan suatu nilai di balik data yang tampak.

Demikian pula pendapat yang dikemukakan oleh Ratna (2015: 47), menjelaskan bahwa metode penelitian kualitatif memberikan perhatian terhadap data alamiah, data dalam hubungannya dengan konteks keberadaannya. Cara tersebut mendorong metode kualitatif dianggap sebagai multimetode, sebab penelitian pada gilirannya melibatkan sejumlah besar gejala sosial yang relevan.

Melalui metode penelitian deskriptif kualitatif peneliti akan menganalisis unsurunsur instrinsik dan ekstrinsik berupa nilainilai sosial yang terdapat dalam kumpulan cerpen Rumah Malam di Mata Ibu karya Alex R. Nainggolan. Kemudian hasil analisis tersebut akan dikaitkan dengan kriteria pemilihan bahan pembelajaran sastra di Sekolah Menengah Atas.

Sumber data penelitian yaitu sumber subjek dari tempat mana data bisa didapatkan. Sumber data dalam penelitian ini menggunakan data primer dan data sekunder, sumber data tersebut adalah sebagai berikut.

\section{a. Data Primer}

Data primer adalah sumber utama dari penelitian ini, yaitu data yang diseleksi atau diperoleh langsung dari sumbernya tanpa perantara (Siswantoro, 2010: 71).
Sumber data primer dalam penelitian ini berupa teks kumpulan cerpen Rumah Malam di Mata Ibu karya Alex R.Nainggolan, judul cerpen "Aku Akan Pergi ke Suatu Tempat", "Angin Mati", “ dijalan Teuku Umar Saya Gemetar" dan "Tahun Baru"

\section{b. Data Sekunder}

Data sekunder adalah data yang diperoleh secara tidak langsung atau lewat perantara, tetapi tetap bersandar kepada kategori atau parameter yang menjadi rujukan (Siswantoro, 2010: 71). Data yang diambil dari berbagai literature yang relevan dengan objek penelitian seperti majalah, website, dan blog di internet.

\section{c. Data Penelitian}

Data dalam penelitian ini mencakup tema, alur, tokoh/penokohan, sudut pandang, amanat, dan nilai-nilai sosial dalan kumpulan cerpen Rumah Malam di Mata Ibu karya Alex R.Nainggolan, kesesuaian bahan ajar dan gambaran model pembelajaran. Data dalam penelitian ini berupa uraian cerita, ungkapan, pernyataan, kata-kata tertulis, melainkan menggunakan angka-angka dengan cara mengumpulkan data-data tersebut.

\section{d. Teknik Penelitian}

Selain metode penelitian, dalam suatu penelitian diperlukan teknik khusus untuk memudahkan penelitian dalam memperoleh data penelitiannya yang akurat. Sugiyono (2012: 224) menjelaskan bahwa teknik pengumpulan data merupakan langkah yang paling strategis dalam penelitian, karena tujuan utama dari penelitian adalah mendapatkan data.

Langkah-langkah yang akan dipakai dalam penelitian ini sebagai berikut.

1. Studi pustaka, yaitu peneliti mencari dan memahami teori-teori yang berkaitan dengan masalah ini penulis mengambil dari buku-buku sumber untuk dijadikan acuan.

2. Teknik baca catat, yaitu peneliti membaca berulang-ulang kumpulan cerpen Rumah Malam di Mata Ibu karya Alex R. Nainggolan. 
3. Teknik analisis, yaitu penelitian menganalisis dan mengkaji kumpulan cerpen Rumah Malam di Mata Ibu karya Alex R. Nainggolan berdasarkan kajian nilai-nilai sosial serta bahan ajar dan model pembelajaran di SMA.

\section{e. Teknik Pengolahan Data}

Langkah-langkah yang peneliti lakukan dalam penelitian ini adalah sebagai berikut:

1. Peneliti membaca kumpulan cerpen Rumah Malam di Mata Ibu karya Alex R. Nainggolan.

2. Peneliti melakukan analisis struktur yang meliputi analisis tema, tokoh, alur, latar dan sudut pandang pada kumpulan cerpen Rumah Malam di Mata Ibu karya Alex R. Nainggolan.

3. Berdasarkan analisis struktur peneliti mencari nilai-nilai sosial yang terdapat di dalam cerpen.

4. Peneliti melakukan analisis layak tidaknya kumpulan cerpen Rumah Malam di Mata Ibu karya Alex R. Nainggolan, sebagai alternatif bahan ajar di SMA.

5. Peneliti melakukan analisis mengenai model pembelajaran yang tepat pada kumpulan cerpen Rumah Malam di Mata Ibu karya Alex R. Nainggolan: dan

6. Peneliti berdasarkan data yang akan digunakan untuk sebagai instrumen analisis nilai-nilai sosial kumpulan cerpen Rumah Malam di Mata Ibu karya Alex R. Nainggolan.

\section{f. Instrumen Analisis}

Instrumen penelitian adalah alat untuk memperoleh data (Sudjana, 2001: 58). Terdapat dua hal utama yang memengaruhi kualitas data hasil penelitian, yaitu, kualitas instrumen penelitian dan kualitas pengumpulan data (Sugiyono, 2009: 59). Lebih lanjut, dijelaskan oleh Sugiyono bahwa dalam penelitian kualitatif, yang menjadi instrumen atau alat penelitian adalah peneliti itu sendiri. Oleh karena itu, peneliti sebagai instrumen juga harus "divalidasi" seberapa jauh peneliti kualitatif siap melakukan penelitian yang selanjutnya terjun ke lapangan. Oleh karena itu, dalam penelitian kualitatif "the researcher is the key instrumen." Jadi peneliti adalah instrumen kunci dalam penelitian kualitatif.

Ditegaskan lebih lanjut oleh Nasution (Sugiyono, 2009: 60) bahwa: dalam penelitian kualitatif, tidak ada pilihan lain daripada menjadikan manusia sebagai instrumen penelitian utama. Alasannya ialah bahwa, segala sesuatunya belum mempunyai bentuk yang pasti. Masalah, fokus penelitian, prosedur penelitian hipotesis yang digunakan, bahkan hasil yang diharapkan, itu semuanya tidak dapat ditentukan secara pasti dan jelas sebelumnya. Segala sesuatu masih perlu dikembangkan sepanjang penelitian itu.

\section{PEMBAHASAN}

\section{Analisis Cerpen "Aku Akan Pergi ke Suatu Tempat"}

Nilai sosial merupakan sebuah konsep abstrak dalam diri manusia mengenai apa yang dianggap buruk, indah, atau tidak indah. Nilai sosial yang berada dilingkungan masyarakat dapat melihat baik buruknya penemuan yang berada ditengah-tengah masyarakat, berbeda-beda sifat, status sosial dan pekerjaan yang pastinya ada sisi negatif dan positif yang dipandang oleh masyarakat. Saat ini di masyarakat lebih cepat merasakan putus asa sebelum berusaha semaksimal mungkin. Seperti pada kutipan berikut ini.

Aku akan pergi ke suatu tempat, lebih baik begitu. Aku tak mau semuanya tinggal angan-angan. Begitu kepingin bersama denganmu, menanti apa saja yang masih mungkin dinanti. Seperti helai-helai daun yang menanti untuk gugur di sebuah tempat. Dan, aku meminta dengan hormat, jangan pernah kepikiran tentang diriku!

(Nainggolan, 2013: 20)

\section{Analisis Cerpen "Angin Mati"}

Nilai sosial merupakan sebuah konsep abstrak dalam diri manusia mengenai apa 
yang dianggap buruk, indah, atau tidak indah. Nilai sosial yang berada dilingkungan masyarakat dapat melihat baik buruknya penemuan yang berada ditengah-tengah masyarakat, berbeda-beda sifat, status sosial dan pekerjaan yang pastinya ada sisi negatif dan positif yang dipandang oleh masyarakat. Manusia diciptakan berpasang-pasangan dan saling membutuhkan satu sama lain. Seperti pada kutipan berikut ini.

aku akan selalu membaca kesemuanya sekuat tenaga. Melayarkan sampan yang berkayu ke dalam hatimu. Menancapkan keinginan yang sama, seperti hikayat dulu si Juliet kecil yang terpesona pada Romeo. Aku ingin melesapkan kegemetaran ini, dimana ku selalu takjub di beningnya matamu. Ada kegemetaran yang beda di sana.

(Nainggolan, 2013: 38)

\section{Analisis Cerpen "di Jalan Teuku Umar, Saya Gemetar"}

Nilai sosial merupakan sebuah konsep abstrak dalam diri manusia mengenai apa yang dianggap buruk, indah, atau tidak indah. Nilai sosial yang berada dilingkungan masyarakat dapat melihat baik buruknya penemuan yang berada ditengah-tengah masyarakat, berbeda-beda sifat, status sosial dan pekerjaan yang pastinya ada sisi negatif dan positif yang dipandang oleh masyarakat. Jangan pernah menyianyiakan kasih sayang orang yang sangat mencintai kita. Seperti pada kutipan berikut ini.

Saya memang masih mencintainya. Setidaknya cinta yang abstrak, tak mampu saya jelaskan. Cinta yang terasa aneh, sebab ketika bertemu maunya ribut melulu, tetapi setelah tidak bertemu, saya senantiasa dihajar rasa rindu yang naik sampai ke ubun-ubun. Membuat saya sering merasa limbung, di kepala saya yang berdenyut itu, ingatan tua itu terbuka.

(Nainggolan, 2013: 71)

\section{Analisis Cerpen "Tahun Baru"}

Nilai sosial merupakan sebuah konsep abstrak dalam diri manusia mengenai apa yang dianggap buruk, indah, atau tidak indah. Nilai sosial yang berada dilingkungan masyarakat dapat melihat baik buruknya penemuan yang berada ditengah-tengah masyarakat, berbeda-beda sifat, status sosial dan pekerjaan yang pastinya ada sisi negatif dan positif yang dipandang oleh masyarakat. Jangan mewariskan adat yang kurang baik kepada generasi penerus bangsa. Seperti pada kutipan berikut ini.

Aku mengingat, tahun baru sebelumnya. Di mana cahaya warnawarni menghiasi langit hitam. Jeritan yang menandakan sepotong kegembiraan baru. Sorak-sorai yang begitu menyengat, membuka keramaian. Orang-orang yang menghabiskan waktu, untuk sebuah tanggal.

(Nainggolan, 2013: 99)

Pembelajaran apresiasi sastra di sekolah masih cenderung kurang mendapat perhatian dari kalangan sekolah pada umum nya. Hal ini kerena mata pelajaran sastra masih kurang penting atau meskipun ada, masih banyak yang beranggapan bahw aspresiasi sastra itu susah. Pembelajaran sastra di maksudkan untuk meningkatkan kemampuan siswa mengepriasi karya sastra. Kegiatan mengapresiasi sastra berkaitan erat dengan latihan mempertajam perasaan, penalaran, dan daya khayal, serta kepekaan terhadap masyarakat, budaya, dan lingkungan. Salah satu prinsip penting dalam pembelajaran sastra adalah pemilihan bahan pembelajaran yang akan disampaikan pada siswa. Penulis mencoba untuk mencari kesesuaian cerpen Rumah Malam di mata Ibu karya Alex $\mathrm{R}$ nainggolan sebagai alternatif bahan pembelajaran sastra di SMA. Ada beberapa aspek yang perlu diperhatikan oleh guru dalam memilih bahan pembelajaran serta sebagai berikut. 


\section{a. Aspek Bahasa}

Dilihat dari segi kebahasaan cerpen Rumah Malam di mata Ibu karya Alex R. Nainggolan cenderung menggunakan bahasa yang cukup komunikatif dalam artian tidak menggunakan kata-kata maupun kalimatkalimat khiasan sehingga cerpen ini dengan mudah bisa dipahami oleh siswa walaupun kadang-kadang diselingi dengan kata-kata yang menggunakan bahasa jawa, tetapi tidak akan menyulitkan para siswa untuk membacanya karena dibawahnya ada penjelasan tentang bahasa tersebut. Aspek bahasa yang terdapat pada cerpen Rumah Malam di mata Ibu karya Alex R. Nainggolan ini sesuai dengan tingkat kemempuan bahasa siswa, sehingga layak untuk dijadikan sebagai bahan pembelajaran serta disekolah, seperti dalam kutipan berikut ini.

Aku selalu dilanda kelinglungan yang panjang, ketika menatap kalender tengah menunjuk bulan Desember. Entah kenapa. Barangkali karena bulan ini terletak di ujung tahun, yang menyibukkan bagi sebagian orang untuk mereka ulang masa lalu. Semacam sengat nostalgia yang terapung, terdampar dalam masa lalu yang sebenarnya tak pernah diulang lagi. Begitu pun tahun ini. Tak ada rencana yang berkelindan di kepalaku, semacam pergi ke kota yang pasti ramai, di mana setiap orang keluar rumah, memajang dirinya.

(Nainggolan, 2013: 83).

Berdasarkan kutipan bahasa yang di gunakan sangatlah mudah dipahami oleh anak SMA karena masing menggunakan Bahasa Indonesia.

\section{b. Aspek Psikologi}

Di lihat dari kematangan jiwa (psikologi) cerpen ini sesuai untuk kalangan remaja khususnya SMA karena pada umumnya pada seusia mereka rasa ingin melakukan atau mencoba sesuatu yang baru itu lebih besar, namun pada cerpen ini tergambarkan tokoh aku yang begitu sederhana tidak menyukai gaya hidup yang glamour dan ia tetap jadi diri sendiri meskipun lingkungan sekitarnya sangat mempengaruhi ia tetap menjadi diri sendiri, seperti dalam kutipan berikut ini.

Berkumpul di suatu tempat, sambil bersorak. Atau barangkali memesan tempat di sebuah kafe, mendengarkan lantunan penyanyi pujaannya. Tetapi aku malah malas, katakanlah untuk sekadar merencanakan menghabiskan tahun baru ke mana atau dengan siapa. Sebab memang aku tak pernah merencanakannya. Aku mengingat, tahun baru sebelumnya. Di mana cahaya warnawarni menghiasi langit hitam. Jeritan yang menandakan sepotong kegembiraan baru. Sorak-sorai yang begitu menyengat, membuka keramaian. Orang-orang yang menghabiskan waktu, untuk sebuah tanggal.

(Nainggolan, 2013: 85)

\section{c. Latar Belakang Budaya}

Karya sastra lahir merupakan cerminan dari keadaan masyarakat pada jamannya serta merupakan bentuk dari sosiokultural yang diolah oleh pengarang dengan daya imajinasinya sehingga menjadi karya besar cerpen Rumah Malam di mata Ibu karya Alex R. Nainggolan merupakan pengelaman pribadi yang dirasakan oleh penulis dan dituangkan dalam suatu karya. Pembelajaran yang dirancang mencoba memperkenalkan kepada siswa supaya lebih jauh memahami dan berpengalaman dalam memahami apresiasi sastra terhadap cerpen. Siswa diharapkan lebih dapat memahami sisi dan makna yang terkandung dalam cerpen tersebut dan mengerti tentang personal moral dalam cerpen seperti berikut ini.

Demikianlah. Desember terasa akan pergi, dan aku merasa sedikit menyesal. Mengapa sedikit? Aku juga tak tahu. Mendadak aku seperti terkesiap, memikirkan Desember yang selalu dirundung keharuan 
panjang, dengan penantian yang juga dipenuhi pengharapan. Seperti ketika suara terompet berbunyi, memenuhi ruangan di setiap sudut, yang melagukan sebuah keyakinan tentang perubahan. Tetapi apakah yang berubah? Hanya sebuah harap-harap cemas, yang semakin panas, sembari menerka kecil-kecil perihal apa yang terjadi di depan nanti. Namun apakah kita mampu menduga segalanya yang akan terjadi di depan? Sebab terkadang apa yang pernah direncanakan saja tak pernah mampu terlaksana dengan sempurna.

(Nainggolan, 2013: 94)

Berdasarkan pada kutipan tersebut jangan menyianyiakan masa muda mu dengan hal-hal yang kurang baik karena masa muda bukan berarti masa yang untuk mencoba segala hal tetapi belajarlah untuk memahami semua hal tanpa melakukan sesuatu yyang nanti akan merugikan dan hanya meninggalkan penyesalan dimasa yang akan datang.

Pembelajaran sastra di sekolah harus sesuai dengan standar kompetensi dan kompetensi dasar. Misalnya standar kompetensi: memahami berbagai hikayat, cerpen dan kompetensi dasarnya: menganalisis unsur-unsur instrinsik dan ekstrinsik cerpen. Pembelajaran ini akan diajarkan di SMA kelas XI.

\section{SIMPULAN}

\section{Simpulan}

Berdasarkan hasil analisis dan pembahasan empat cerpen yang terdapat dalam kumpulan cerpen Rumah Malam di Mata Ibu karya Alex R. Nainggolan, dapat disimpulkan sebagai berikut.

a) Cerpen-cerpen yang dianalisis memiliki nilai sosial meliputi hubungan manusia dengan diri sendiri, orang lain, lingkungan dan tuhan. Hubungan manusia dengan diri sendiri adalah sebagai berikut.
1) Hidup penuh dengan kesederhanaan dengan tidak menyianyiakan masa mudanya terdapat dalam satu cerpen, yaitu "Tahun Baru".

2) Bertanggung jawab dan peduli terhadap sesama, terdapat dalam satu cerpen, yaitu "Aku akan pergi ke suatu tempat".

3) Tolong menolong dalam sesama terdapat dalam satu cerpen, yaitu "Angin Mati".

4) Berbuat jujur, memberikan kasih sayang, dan mementingkan orang lain terdapat dalam satu cerpen, yaitu "di Jalan Teuku Umar saya Gemetar”.

b) Hubungan manusia dengan orang lain adalah sebagai berikut.

1) Selalu menepati janji dengan orang lain terdapat dalam satu cerpen, yaitu "Aku Akan Pergi ke Suatu Tempat".

2) Melepaskan dan mengikhlaskan orang yang kita sayangi terdapat dalam cerpen, yaitu "Angin Mati".

3) Memuji dan menghargai orang lain terdapat dalam cerpen, yaitu "di Jalan Teuku Umar saya Gemetar".

4) Persahabatan dan berhubungan baik dengan orang lain terdapat dalam cerpen, "Tahun baru".

c) Hubungan manusia dengan lingkungan adalah sebagai berikut.

1) Rasa peduli antar sesama terdapat dalam satu cerpen, yaitu "di Jalan Teuku Umar Saya Gemetar".

2) Mengerti arti kesederhanaan hidup terdapat dalam satu cerpen, yaitu "Tahun Baru".

3) Sikap tolong menolong dan gotong royong terdapat dalam empat cerpen, yaitu "Angin Mati”.

d) Cerpen-cerpen yang terdapat dalam kumpulan cerpen Rumah Malam di Mata Ibu karya Alex R. Nainggolan layak dijadikan sebagai alternatif bahan ajar di SMA karena dari segi bahasa cerpen itu mudah dipahami karena menggunakan bahasa sehari-hari. Faktor lain yang menjadi pertimbangan adalah 
dari aspek psikologis, karena siswa SMA berada pada usia remaja yang akan antusias jika diajak pada pembicaraan masalah percintaan dan terdapat pembelajaran yang dapat mereka pembelajari di usia remaja seperti hormat kepada orang tua dan rela berkorban demi orang lain, contohnya dalam cerpen "Angin Mati", dan "di jalan Teuku Umar Saya Gemetar". Faktor pertimbangan selanjutnya adalah aspek latar budaya, karena cerpen tersebut dapat memberi pengetahuan kepada siswa bagaimana situasi desa dan norma masyarakat timur, seperti dalam cerpen "Tahun Baru" dan "Aku Akan Pergi ke Suatu Tempat".

\section{Saran}

Berdasarkan hasil analisis cerpencerpen yang terdapat dalam kumpulan cerpen Rumah Malam di Mata Ibu karya Alex R. Nainggolan, peneliti mengajukan saran-saran berikut.

1. Nilai Sosial dan hal positif yang terdapat dalam kumpulan cerpen Rumah Malam di Mata Ibu karya Alex R. Nainggolan, sebaiknya dapat menjadi pelajaran dan dapat diteladani siswa agar menjadi pribadi yang lebih baik.

2. Guru Bahasa Indonesia dapat membaca, mempelajari, memahami, mempertimbangkan dan menjadikan kumpulan cerpen Rumah Malam di Mata Ibu karya Alex R. Nainggolan sebagai salah satu alternatif bahan ajar di SMA dengan melibatkan siswa secara langsung dalam kegiatan membaca, menikmati, dan mengapresiasi karya sastra.

3. Guru selalu meningkatkan pengetahuan dan kemampuan sebagai bekal dalam melaksanakan proses belajar mengajar. Guru hendaknya tidak berhenti untuk berkreativitas untuk meningkatkan mutu hasil belajar, serta mampu memilih metode pembelajaran yang tepat dan sesuai dengan materi yang akan diajarkan kepada siswa dengan memerhatikan aspek penting dalam memilih metode pembelajaran agar siswa lebih aktif dan tidak merasa jenuh dalam mengapresiasi sastra.

4. Siswa difasilitasi dalam belajar dan diarahkan apa saja hal yang perlu dilakukan dalam mengapresiasi sastra karena pada kurikulum 2013 revisi 2016 siswa yang dituntut untuk menemukan dan merumuskan sendiri apa yang ditemukannya.

\section{DAFTAR PUSTAKA}

Al- ma'ruf, 2009. Apresiasi karya sastra Yogyakarta: Pustaka Penerbit Pinus.

Al- Ma'ruf, 2010. Apresiasi karya sastra Yogyakarta: Pustaka Penerbit Pinus.

Aminuddin. 2013. Pengantar Apresiasi Karya Sastra. Bandung. Sinar Baru Algesindo.

Aksan, Hermawan. 2015. Proses Kreatif Menulis Cerpen Bandung: Nuansa Cendekia.

Arzia, 2011 Analisis Sosiologis Cerpen Si Padang Karya Ardini Pangastuti B.N.' Jurnal Humaniora Vol. 23 (3). Hal. 245-255.

Damono, 1978. Pengkajian Sosiologi Sastra. Bandung: Nuansa Cendekia.

Endraswara, Suwardi. 2013. Metodologi Penelitian Sastra: Epistemologi, Model, Teori, Dan Aplikasi. CAPSCenter For Academic Publishing Service: Yogyakarta.

Faruk. 2016. Pengantar Sosiologi Sastra Dari Strukturalisme Genetik Sampai Post- Modernisme. Yogyakarta: Pustaka Pelajar. 
Johnson. 2007. Metodologi Penelitian Kualitatif: Dasar, Teori, dan Terapannya dalam Penelitian. Surakarta: UNS Press.

Kosasih. 2004. Teori Pengkajian Sastra. Bandung: Titian Ilmu.

Maryanto. 2009. Bahasa Indonesia Yogyakarta: Pustaka.

Nainggolan, R. Alex. 2013. Kumpulan Cerpen Rumah Malam Di Mata Ibu. Jakarta. Pensil-324.

Nurgiyantoro, Burhan. 2000. Teori Pengkajian Fiksi. Yogyakarta: Gajah Mada University Press.

Nurgiyantoro, Burhan. 2002. Teori Pengkajian Fiksi. Yogyakarta: Gajah Mada University Press.

Nurhadi dan Agus gerard, 2003. Metode Pengajaran Sastra. Yogyakarta: Kanisius.

Permendikbud RI Nomor 24 Tahun 2016 Tentang Kompetensi Dasar Pelajaran Pada Kurikulum 2013 Pada Pendidikan Dasar dan Pendidkan Menengah.

Permendikbud RI Nomor 22 Tahun 2016 Tentang Standar Proses Pendidikan Dasar dan Menengah.

Rahmanto, B. 1988. Metode Pengajaran Sastra. Yogyakarta: Penerbit Kanisius.

Ratna, Nyoman Kutha. 2015. Teori, Metode dan Teknik Penelitian Sastra. Yogyakarta: Pustaka Pelajar.

Ratna, Nyoman Kutha. 2013. Paradigma Sosiologi Sastra. Yogyakarta: Pustaka Pelajar.
Ratna, Nyoman Kutha. 2003. Paradigma Sosiologi Sastra. Yogyakarta: Pustaka Pelajar.

Rusman. 2016. Model-model Pembelajaran Mengembangkan Profesionalisme Guru. Jakarta: PT Raja Grafindo Persada.

Rohman. 2012. Metodelogi Pembelajaran. Yogyakarta: Pustaka Pelajar.

Santosa, Andi. 2011. Metode dan Teknik Pembelajaran. Surakarta Yuma Presindo.

Setiadi, Elly M. 2013. Ilmu sosial budaya dasar. Jakarta: kencana.

Simanjuntak, 2002. Kajian Nilai Sosial. Yogyakarta: Pustaka Pelajar.

Stanton, 2007. Kajian Sastra. Surakarta: Widya Sari Press.

Soekanto, Soejono, 2000. Nilai sosial dalam masyarakat. Padang: Angkasa Raya.

Sukmadinata, Nana Syaodih. 2002. Teori Penelitian Sastra. Yogyakarta: Pustaka Pelajar.

Suprijono, 2009. Model Pembelajaran Sastra. Yogyakarta: Pustaka Pelajar.

Wellek, Rene and Austin Warren. 1956. Teori Kesustraan (terjemahan Melani Budianta). Jakarta: Gramedia.

Teeuw A, 2015. Sastra dan ilmu sastra bandung PT. Dunia Pustaka Jaya.

Tim penyusun. 2012. Kamus besar bahasa indonesia jakarta : pustaka phoenik.

Waluyo, J. Herman. 2002. Apresiasi dan Pengajaran Sastra. Surakarta: UNS Press. 
BAHTERA INDONESIA:

ISSN 2541-3252

Jurnal Penelitian Pendidikan Bahasa dan Sastra Indonesia

Vol. 3, No. 2, Sep. 2018

Yassin, HB. 1991. Tifa Penyair dan Daerahnya. Jakarta: Haji Masagung. 